\title{
Provide Student Knowledge About How Response On Growth Of Vetiver Seeds (Vetiveria zizanioides) In Saline Soil To Ascorbic Acid on Field Practice Learning of Plant Physiology
}

Aisar Novita ${ }^{1}$, Suwandi Saragih ${ }^{2}$, Efrida Lubis $^{3}$, Abdul Rahman Cemda ${ }^{4}$, Fitria ${ }^{5}$, Rini Susanti ${ }^{6}$, Silvia Nora ${ }^{7}$, Arie Hapsani Hasan Basri ${ }^{8}$, Merlyn Mariana

${ }^{1}$ Aisar Novita is a lecturer of Muhammadiyah University, Sumatera Utara, Indonesia email: aisarnovita@umsu.ac.id

${ }^{2}$ Suwandi Saragih is a Graduate of Muhammadiyah Sumatera Utara, Indonesia suwandisaragih@gmail.com

${ }^{3}$ Efrida Lubis is a Lecturer of Muhammadiyah University, Sumatera Utara, Indonesia emai: efridalubis@umsu.ac.id

${ }^{4}$ Abdul Rahman Cemda is a Lecturer of Muhammadiyah University, Sumatera Utara, Indonesia

Email : 4saudara44@gmail.com

${ }^{5}$ Fitria is a Lecturer of Muhammadiyah University Sumatera Utara, Indonesia Email : fitria@umsu.ac.id

${ }^{6}$ Rini Susanti is a Lecturer of Muhammadiyah University Sumatera Utara, Indonesia Email : rinisusanti@umsu.ac.id

${ }^{7}$ Silvia Nora is a Lecturer of Politeknik Pembangunan Pertanian, Medan, Indonesia. Email : silvianora6644@gmail.com

${ }^{8}$ Arie Hapsani Hasan Basri is a Lecturer of Politeknik Pembangunan Pertanian, Medan, Indonesia.

Email : arie_hapsani@yahoo.com

${ }^{9}$ Merlyn Mariana is a lecturer of Politeknik Pembangunan Pertanian, Medan, Indonesia. Email : merlynmariana80@gmail.com

\begin{abstract}
Vetiver root is a commodity that is tolerant enough to be planted in salty soils with a certain level of salinity. One approach to increase oxidative stress tolerance that will increase the enzyme substrate at the cellular level is ascorbic acid. The purpose of this study was to increase students' knowledge about how the response of vetiver seed (Vetiveria zizanioides) growth in salt soils to ascorbic acid through practical field learning in plant physiology courses. This research was conducted using a factorial randomized block design (RBD), the first factor was the salinity (S), namely S0: $0 \mathrm{dsm}-1$ and S1: $4 \mathrm{dsm}-1$. The second factor was ascorbic acid (A), namely A0: without treatment, A1: 50 ppm, A2: $100 \mathrm{ppm}$ and A3: $150 \mathrm{ppm}$. There were 8 treatment combinations that were repeated 3 times resulting in 24 experimental units. The parameters observed were plant height, number of leaves and number of stomata. In this study, ascorbic acid had a significant effect on plant height, number of leaves and number of stomata. Saline soil had a significant effect on the number of stomata parameters. No interactions for all parameters were observed.
\end{abstract}

Keywords : Vetiveria zizanioides, ascorbic acid, saline soil 


\section{INTRODUCTION}

The learning System carried out in the plant physiology field practice course is carried out through: 1. Student centered learning: divided into discussion groups, student presentations, plus material from the lecturer. 2. Research university: lecturers provide examples of their research results for lecture materials and 3. eLearning: materials prepared by lecturers and supporters can be accessed via elearning UMSU.

Educators need to improve the quality of learning, starting with a good learning design by paying attention to the objectives, student characteristics, the material being taught, and the available learning resources. In fact, there are still many learning processes that are of less quality, inefficient and less attractive, and even tend to be boring, so that the learning outcomes achieved are not optimal (Sulastri, 2015). One of the learning models is a problem-based learning model. Students are expected to be active in doing practicum independently so that when doing research for the thesis, students will be more familiar with the research that will be done. According to Nurbaiti (2019), states that if students are actively involved in learning, then students will understand the concept well, remember it longer and will be able to use the concept in other contexts. One of the effective learning models that can be applied so that students become active and creative in the learning process is the problem-based learning model or better known as Problem Based Learning (PBL).

In this lesson, the lecturer provides examples of the results of research that have been carried out as learning materials. The research results presented in this study are related to one of the materials from the plant physiology course, namely plant metabolism. Plant Physiology discusses the relationship between plants and water, nutrient requirements, enzymes, carbon, nitrogen and sulfur metabolism, water translocation, nutrients and metabolic products, growth and development, hormones, motion, seed germination, dormancy and environmental stress. Plant Physiology is the study of all internal plant activities - the chemical and physical processes associated with plant life. study how plants function, how energy from sunlight is used for carbon assimilation, how plants get and distribute nutrients and water, how plants grow and develop, how plants respond to their surrounding environment, how plants adapt to vulnerable conditions, and how plants reproduce, how plants expand their habitats. For this reason, Plant Physiology studies the shape and arrangement of plant parts, their functions, processes and mechanisms of action. To explain all this, Plant Physiology needs the help of other fields of biology, physics, and chemistry, which in later developments also include thermodynamics and mathematics. Plant Physiology is study and research about plant life, how the processes of life and plants, functions and activities of plants themselves. Oktaviani et al (2019), said that students develop skills not only practicum, but also provide ideas that are useful in learning, namely when presenting experimental data in the form of posters. Presentation of these results is carried out by students applying all the knowledge they have both from the beginning of writing to the presentation of the results presented.

In the field of plant physiology learning practice, one of the materials provided is about metabolism in plants which is related to the process of environmental stress. Students need to know how the effects of plants are caused by environmental stress. One of the environmental stresses that occur in plants is saline soil. In addition to Jurnal Serambi Ilmu Journal of Scientific Information and Educational Creativity 
metabolism in plants related to environmental stress, plant physiology practicum also studies plant metabolite compounds. Ascorbate is the main metabolite compound in plants that has an antioxidant function, which protects plants from oxidative damage resulting from aerobic metabolism, photosynthesis and various pollutants. Soil that contains salinity becomes more saline so that the soil cannot absorb water from the soil. This is because plants or plants contain various concentrations of ions (salts) which make natural water flow from the soil to the plant roots when the soil has high enough saline, it can inhibit the movement of water from plant roots to be pulled back into the soil so that the plant cannot take enough water for the growth process. If the concentration of residual salinity in the soil is high enough, plants will wither and die regardless of the amount of water applied (Novi $d k k ., 2016$ ).

Saline soils are an example and salinity is a major abiotic limiting factor in reducing plant growth and production. High salinity can reduce crop production (Temel et al. 2016; Alcívar et al. 2018; Suárez-Hernández et al. 2019), especially in dry areas; cause ion / nutrient imbalance, osmotic pressure, and oxidative in plant tissues (Zhu 2001); inhibits the synthesis of photosynthetic pigments and the photosynthetic process (El-Ramady et al. 2018). Soil is infected by salt due to many factors, the more salt that accumulates in the soil, making the salinity increase this process is called salinization. The process of accumulation of salt in the soil can occur naturally and can also occur indirectly due to human activities. Salinization caused by human activities is called secondary salinization because the growing needs and interests of human life, indirectly cause the soil to gradually accumulate salt. Secondary salinization causes problems in agriculture due to the increase in saline soil. Exclusion is one of the adaptations of plants in dealing with salinity stress. Sopandie (2013) states that the exclusion mechanism is a mechanism to prevent water deficit internally by synthesizing organic solutes and increasing succulence. Plants that have an exclusion mechanism only store salt in very low concentrations in the stems and shoots because the plants are able to retranslocate salt back to the root area. Plants usually synthesize molecules that can lower the osmotic potential. This mechanism makes water retained in cells and water in the environment can be absorbed by the roots to maintain a turgor state (Novenda \& Nugroho, 2016). Osmotic molecules are usually compounds from the sugar and amino acid groups, plants synthesize osmotic molecules with an equivalent exchange, namely a decrease in plant biomass and a greater amount of ATP (energy) loss (Kurniawati. 2014).

Vetiver vetiver (Vetiveria zizanioides L.) is an important essential oil producer in the world. Indonesia is one of the top three vetiver oil producers in the world today. However, Indonesia is only able to meet about $28 \%$ of the world's vetiver oil needs. This is because the productivity of vetiver is still low. The yield of vetiver oil is very low, namely 1.5 - $2 \%$ dry weight, Vetiver root is an example of a plant that has the potential to be used as high-value agricultural goods or products, vetiver is one of Indonesia's leading export commodities with potential. The area of vetiver plant land in Indonesia reaches 3,200 ha (Pipit $d k k$., 2014).

Akar Wangi (Vetiveria zizanoides L.) is a clumpy perennial plant with lush roots that grows straight into the ground. This plant originates from India, Southeast Asia and tropical Africa. Vetiver plants are resistant to heavy metals, salinity and can grow at a $\mathrm{pH}$ between 3 - 11.5 so that they can be used to rehabilitate the physical and chemical 
conditions of damaged soil. The high absorption or accumulation of heavy metals in plant tissue is very tolerant of drought and floods, frost, heat, extreme soil $\mathrm{pH}, \mathrm{Al}$ and Mn toxicity, and very tolerant of various metals such as $\mathrm{As}, \mathrm{Cd}, \mathrm{Cu}, \mathrm{Cr}$, and $\mathrm{Ni}$ (Aini dan Idris, 2015).

One of the efforts to increase tolerance to oxidative stress is the application of ascorbic acid (vitamin C). Ascorbic acid is a small, water-soluble, antioxidant that acts as the main substrate in the cyclic enzymatic detoxification pathway of hydrogen peroxide. Ascorbic acid is the first substance in detoxifying and neutralizing superoxide radicals. Ascorbic acid also plays an important role in photoprotection, photosynthesis regulation, and plant growth processes such as cell division and cell wall expansion (Ardiansyah, 2014).

The antioxidant activity of ascorbic acid is associated with plant resistance to oxidative stress. Then the endogenous level of ascorbic acid becomes very important in the regulation of aging development (Farouk, 2011). Another function of ascorbate is in iron metabolism by maintaining iron at a reduced level of ascorbate thereby promoting iron absorption. In addition, ascorbate also mobilizes iron from ferritin deposits (Drevan, 2011). Thus, to provide direct experience for students it is necessary to conduct field experiments about response on growth of vetiver seeds (vetiveria zizanioides) in saline soil to ascorbic acid field practice learning of plant physiology based on related references.

\section{METHODS}

The research was conducted as a learning method of Plant Physiology in a screen house in the experimental field at the Faculty of Agriculture, Muhammadiyah University of North Sumatra, Medan. The materials used in the implementation of this study were 3 month old Vermiata root seeds from the city of Bogor, West Java, varieties of Verina, ascorbic acid, salt, saline soil, chlorophyll meter, meter, knife, machete, ruler, stationery, oven, hoe, treatment signpost. , analytical scales, refractometer, sprayer, camera, cutex, microscope and beaker glass.

The study method used was a factorial randomized block design (RBD) used in this study with two factors studied, namely: The first factor was salinity treatment (S), there were 2 levels, namely: S0: Without Salinity (0 dsm-1) and S1: Salinity (4 dsm-1). The second factor is the concentration level (A), which consists of four levels, namely: A0: 0 control, A1: $50 \mathrm{ppm}, \mathrm{A} 2: 100 \mathrm{ppm}$ and A3: $150 \mathrm{ppm}$. There were 8 treatment combinations with 3 repetitions, the spacing used was $20 \mathrm{~cm} \times 20 \mathrm{~cm}$, the distance between replicates was $50 \mathrm{~cm}$. As for the size of the poly bag used is $35 \mathrm{~cm} \mathrm{x} 40 \mathrm{~cm}$, the number of plants per plot is 5 plants, the total number of sample plants is 72 , the total number of plants is 120 plants. Study data were analyzed by using the Duncan Multiple Range Test (DMRT) at the 5\% level.

\section{RESULTS AND DISCUSSION}

Ascorbic acid at the age of 6 WAP had a significant effect, on the other hand, saline soil had no significant effect, there was no interaction between the two treatments, as shown in Table 1. 
Table 1.

Average Plant Height on Ascorbic Acid to Vetiver Seeds aged 2-6 WAP.

\begin{tabular}{lccc}
\hline \multirow{2}{*}{ Treatment } & \multicolumn{3}{c}{ WAP } \\
\cline { 2 - 4 } Saline Soil & \multicolumn{3}{c}{6} \\
S0 & 33,00 & 90,17 & 128,31 \\
S1 & 29,97 & 68,92 & 101,08 \\
Ascorbic Acid & & & \\
A0 & 30,17 & 76,65 & $107,78 \mathrm{~b}$ \\
A1 & 32,22 & 81,11 & $109,67 \mathrm{ab}$ \\
A2 & 32,17 & 74,28 & $111,61 \mathrm{ab}$ \\
A3 & 31,39 & 86,22 & $129,72 \mathrm{a}$ \\
\hline
\end{tabular}

Notes: The numbers followed by different letters in the same column are significantly different according to the 5\% DMRT test.

Table 1 shows that the lowest of ascorbic acid was treatment A0 (107.78), significantly different from A3 (129.72) but not significantly different from A1 (109.67) and A2 (111.61) at the age of 6 wap. Using regression analysis and correlation, the relationship between ascorbic acid and plant height can be seen in Figure 1.

Figure 1.

Graph of Plant Height at 6 WAP on Ascorbic Acid

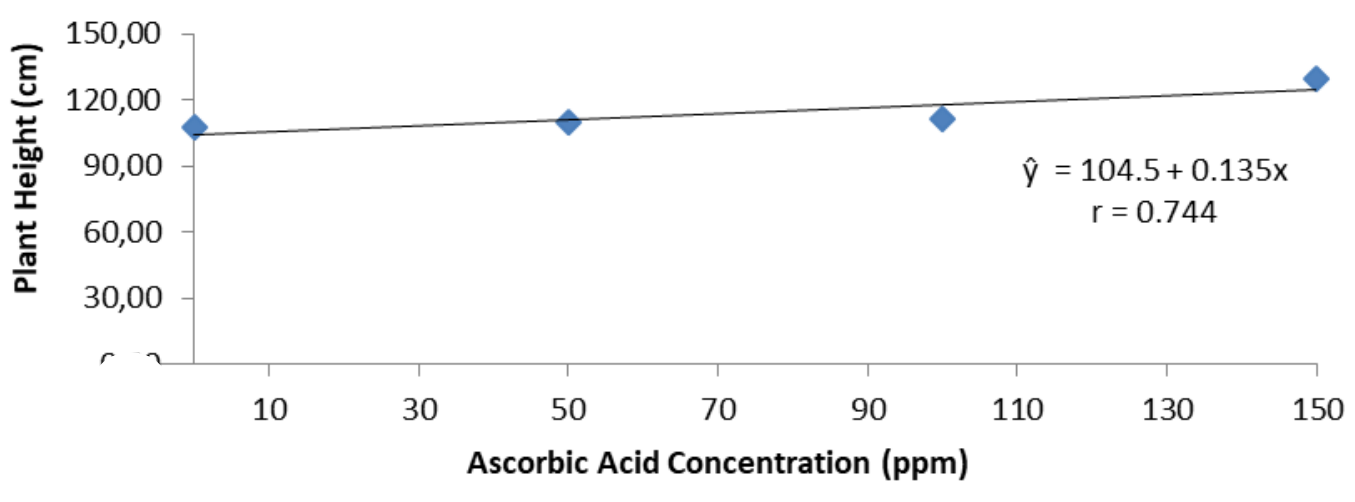

Figure 1 shows a positive linear relationship, which means that plant height has increased in giving $\mathrm{A} 1$ and increases in $\mathrm{A} 2$ with the regression equation $\mathrm{y}=0.135 \mathrm{x}+$ 104.5 with a value of $r=0.744$.

The Ascorbic acid at a dose of $150 \mathrm{ppm}$ had a significant effect. The higher the dose given, the better the growth. The increase in plant height growth was obtained after the application of Ascorbic Acid (Saragih, 2020). This increase occurred because the effect of salinity stress was immediately resolved with availability in line with Hasan (2017) that ascorbic acid as an antioxidant during stress. The increase in plant height growth was obtained after the application of Ascorbic Acid. This increase occurred because the effect of salinity stress was immediately resolved by the availability of 
ascorbic acid as an antioxidant during stress. Agronomically, the strategy to overcome the problems in this marginal land is to use plants that are tolerant of salinity stress. Plants that are stressed by salinity also experience oxidative stress which results in inhibition of photosynthetic processes such as electron transport. One approach to promote oxidative stress tolerance that will increase the enzyme substrate at the cellular level is ascorbic acid. Ascorbic acid functions as an antioxidant, enzyme cofactor and as a modulator of cell signaling in a variety of important physiological processes, including cell wall biosynthesis, secondary metabolites and phytohormones, stress tolerance, photoprotection, cell division and growth (Wolucka et al, 2005).

Based on the results of the analysis, it shows that the application of ascorbic acid to the growth of vetiver seeds found in spines 10-15 had a significant effect on the number of leaves when the plant was $6 \mathrm{WAP}$, otherwise saline had no significant effect and there was no interaction between the two, shown in Table 2.

Table 2 shows that ascorbic acid had a significant effect on the parameter number of leaves at $6 \mathrm{WAP}$ with the highest in treatment A3 $(11,39)$ which was significantly different from A0 (9.28) but not significantly different from A1 (10.00) and A2 $(10,89)$. Regression analysis and correlation were used to see the relationship between ascorbic acid and the number of leaves presented in Figure 2.

Figure 2 explains the existence of a positive linear relationship, there is an increase in $\mathrm{A} 1$ and more in $\mathrm{A} 2$ with the regression equation $\mathrm{y}=0.014 \mathrm{x}+9.305$ with a value of $r=0.989$ (Saragih, 2020).

Table 2.

Average Number of Leaves on Ascorbic Acid and Soil Saline to vetiver seeds aged 2-6 WAP.

\begin{tabular}{|c|c|c|c|}
\hline \multirow{2}{*}{ Treatment } & \multicolumn{3}{|c|}{ WAP } \\
\hline & 2 & 4 & 6 \\
\hline Saline Soil & & lai..... & \\
\hline $\mathrm{S}_{0}$ & 2,63 & 7,22 & 11,25 \\
\hline $\mathrm{S}_{1}$ & 1,89 & 4,86 & 8,53 \\
\hline Ascorbic Acid & & & \\
\hline $\mathrm{A}_{0}$ & 2,11 & 6,22 & $9,28 b$ \\
\hline $\mathrm{A}_{1}$ & 2,17 & 5,17 & $10,00 \mathrm{ab}$ \\
\hline $\mathrm{A}_{2}$ & 2,28 & 6,06 & $10,89 \mathrm{ab}$ \\
\hline $\mathrm{A}_{3}$ & 2,28 & 6,72 & $11,39 a$ \\
\hline
\end{tabular}


Notes: The numbers followed by different letters in the same column are significantly different according to the 5\% DMRT test

Figure 2.

Graph of the number of leaves aged 6 WAP on Ascorbic Acid

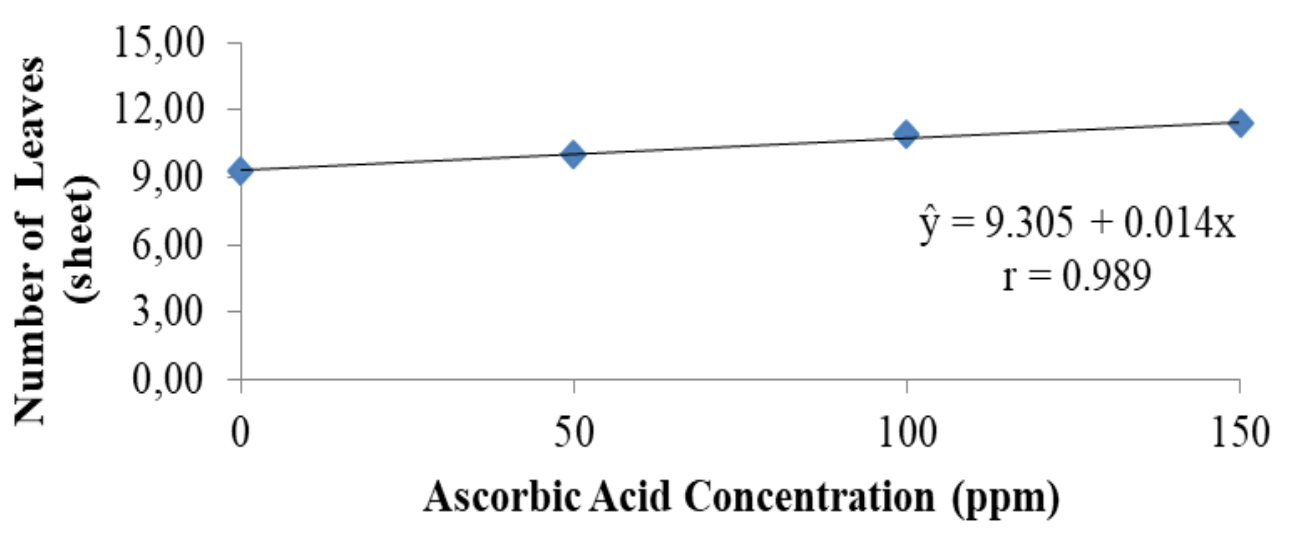

The application of ascorbic acid is thought to be able to protect cells from reactive oxygen compounds and free radicals that interfere with the function of chloroplasts, so that plants can photosynthesize properly which supports increased production, especially the number of productive branches. Rahmawati et al (2014) stated that ascorbic acid treatment can reduce the negative impact of high salt concentrations, namely protecting the function of chloroplasts, thereby reducing the concentration of Reactive Oxygen Species (ROS). Salama et al (2014), stated that Ascorbic acid is a natural plant product that has important functions as an antioxidant and an enzyme and appears to have an important role in reducing cofactors. It participates in various processes. Ascorbic acid is associated with photosynthetic oxidative stress chloroplasts. Besides, ascorbic acid has a number of other roles in cell division and protein modification. One approach to promoting oxidative stress tolerance would be to act as the primary substrate in the cyclic enzymatic detoxification pathway of hydrogen peroxide.

Ascorbic acid in salinity stress conditions showed a significant effect on the number of leaves, ascorbic acid in salinity stress conditions in vetiver plants helped maintain the success of the number of leaves. Novita et al (2015) This is because ascorbic acid is given by spraying it directly on vetiver plants so that it shows the success of its growth. Water requirements that are hampered by absorption and transport can cause cell division to be disrupted and inhibited. Azarmi et al. (2010) reported that plant height and number of tomato leaves decreased significantly with increasing salinity concentration. This is one form of plant adaptation to reduce evaporation due to the water deficit obtained due to disruption of the water and nutrient transportation system, so that plants shed their leaves. High salinity media can reduce the number of 
branches. The same thing was confirmed by Wijayanti et al. (2014), that salinity stress can affect agronomic properties and the number of productive branches of peanuts.

Ascorbic acid had a significant effect on the parameters of the number of stomata and saline soil at 6 WAP but there was no interaction between the two, which is presented in Table 3.

Table 3.

Average Number of Stomata on Ascorbic Acid and Soil Saline to Vetiver Seeds aged 6 WAP.

\begin{tabular}{cccccc}
\hline \multirow{2}{*}{ Saline Soil } & \multicolumn{4}{c}{ Ascorbic Acid } & \multirow{2}{*}{ Average } \\
\cline { 2 - 4 } & $\mathrm{A}_{0}$ & \multicolumn{1}{c}{$\mathrm{A}_{1}$} & $\mathrm{~A}_{2}$ & $\mathrm{~A}_{3}$ & \\
\hline & $\ldots \ldots \ldots \ldots \ldots \ldots \ldots \ldots \ldots \ldots \ldots \ldots \ldots \ldots \ldots \ldots \ldots \ldots$ & \\
$\mathrm{S}_{0}$ & 4.22 & 4.56 & 4.67 & 6.00 & $4.86 \mathrm{a}$ \\
$\mathrm{S}_{1}$ & 3.22 & 3.67 & 4.00 & 3.33 & $3.56 \mathrm{~b}$ \\
\hline Average & $3.72 \mathrm{~b}$ & $4.11 \mathrm{ab}$ & $4.33 \mathrm{ab}$ & $4.67 \mathrm{a}$ & \\
\hline
\end{tabular}

Notes: Numbers followed by different letters on the same line are significantly different according to the $5 \%$ DMRT test

Table 3 explains that ascorbic acid had a significant effect on the parameters of the number of stomata at $6 \mathrm{WAP}$ with the highest in treatment A3 (4.67) which is significantly different from A0 (3.72) but not significantly different from A1 (4.11) and A2 (4.33).

Regression and correlation analysis were used to see the relationship between ascorbic acid and the number of stomata presented in Figure 3.

Figure 4.

Graph of the number of stomata aged $6 \mathrm{WAP}$ on ascorbic acid

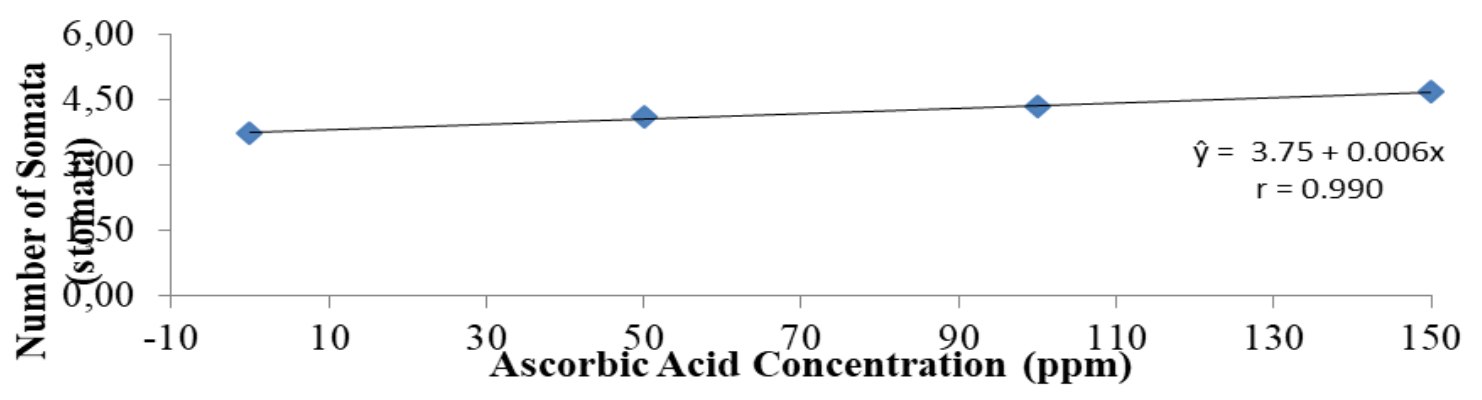

Figure 4 explains the existence of a positive linear relationship, namely there is an increase in $\mathrm{A} 1$ and more in $\mathrm{A} 2$ with the regression equation $\mathrm{y}=0.006 \mathrm{x}+3.75$ with a value of $r=0.990$ (Saragih, 2020).

Stomata are the components of photosynthesis and transpiration which are located in the surface of the leaf in the form of microscopic pores. The effect of salinity 
stress will reduce the number of stomata per unit area and cover the stomata to regulate water balance (Purwaningrahayu and Taufik, 2017).

Salinity treatment can reduce the rate of photosynthesis (Sobir et al. 2018). Nemati et al. (2011) reported that salinity stress causes an increase in ion concentration which is toxic to plants so that it can cause premature aging and reduce the photosynthetic ability of plants. Mazher et al. (2007) also stated that plant growth is limited by an excessive reduction in the rate of photosynthesis due to salt uptake. Apart from reducing the rate of photosynthesis, salinity can also reduce the conductance of stomata (Sobir et al. 2018). Koyro (2006) adds that stomatal conductance reduction is an adaptation mechanism to overcome excessive salt. Salinity also causes a decrease in the transpiration rate due to a lack of water supply that enters the plant tissue, so that plants save water that leaves the plant tissue through the evaporation process by reducing the transpiration rate (Sobir et al. 2017). Ruiz-Sánchez et al. (2000) stated that plants employ an avoidance or preventive mechanism to minimize water loss through transpiration when the stomata are closed.

Krismiratsih (2020) in his research results stated that the increasing the intensity of $\mathrm{NaCl}$ salt stress will reduce the number of stomata per unit area. The decrease in the number of stomata per unit area occurs due to osmotic stress due to potential differences between plant roots and soil solution which causes stomata closure due to lack of cell expansion at young leaf tips, besides stomata closure will cause a decrease in water loss due to the abscisic acid response to the mechanism response. protection will limit $\mathrm{Na}$ and $\mathrm{Cl}$ in leaves, $\mathrm{ABA}$ will also limit transport and water loss by covering the stomata. Stomata closure is also influenced by the presence of $\mathrm{Ca}$ in the cytoplasm which causes a loss of turgor pressure in guard cells (Arifiani et al. 2018).

Ascorbic acid can neutralize toxins, protect cells from reactive oxygen compounds and free radicals and prevent cell death. So that it can cause good plant growth including the number of stomats. In line with the explanation (Rachmawati et al., 2009) ascorbic acid is the main metabolite compound in plants that has a function as an antioxidant, which protects plants from oxidative damage. Ascorbic acid plays an important role in plant germination and growth because it can neutralize toxins, protect cells from reactive oxygen compounds and free radicals and prevent cell death. 
Figure 4.

Graph of the number of stomata aged 6 WAP to the provision of Salin Soil

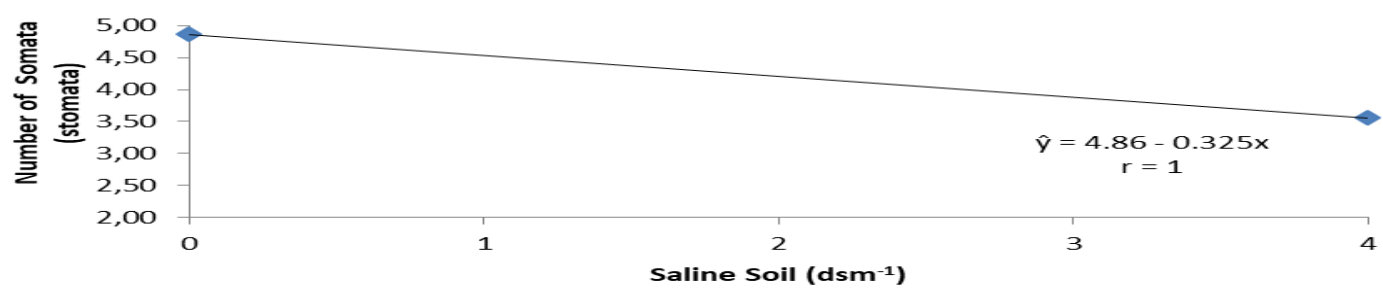

Figure 4 explains that ordinary soil is better than saline soil, that is, the highest number of stomata is seen on ordinary soil with the regression equation $y=4.86 x-$ $0.325 \mathrm{x}$ with a value of $\mathrm{r}=1$. The same thing was stated by Novita (2020), stating that The salinity stress treatment showed a significant effect on reducing the initial growth of vetiver (Vetiveria zizanioides) seedlings on the growth parameters of leaf dry weight, number of stomata and culture thickness.

The plant's first response to a severe stress deficit is to close the stomata. Closure or narrowing of stomata inhibits the process of photosynthesis, this involves the transportation of water in the plant body and decreasing the flow of carbon dioxide in the leaves. Sudjino et al (2017) stated that the size and density of stomata are related to resistance to salinity. In plants experiencing salinity stress, the number of stomata has increased to reduce water loss during transpiration which means that leaves with a high stomatal index are more resistant to stress than leaves with a low stomata index.

\section{CONCLUSION}

The implementation of practical learning methods in the plant physiology course is a method to facilitate students in understanding directly, while providing real knowledge that ascorbic acid has a significant effect on plant height, number of leaves and number of stomata of vetiver seeds. Saline soil has a significant effect on the number of stomata of vetiver seeds. There was no interaction response of vetiver seed for all parameters observed in the saline soil to ascorbic acid.

\section{REFERENCES}

- Aini, R. dan Idris, K., 2010. Pengunaan Tanaman Akar Wangi (Vetiveria zizanioides) Untuk Menyisihkan Logam Timbal Pada Tanah Tercemar Lindi. Jurnal Teknik Lingkungan, Vol. 16 No. 1, April 2010 (hal. 21-30)

- Alcívar M, Zurita-Silva A, Sandoval M, Muñoz C, Schoebitz M. 2018. Reclamation of Saline-Sodic Soils with Combined Amendments: Impact on Quinoa Performance and Biological Soil Quality. Sustainability. 10: 1-27. https://doi.org/10.3390/ su10093083

- Ali Ardiansyah, M., 2014. Respon Pertumbuhan dan Produksi Kedelai Hasil Seleksi Terhadap Pemberian Asam Askorbat dan Inokulasi Jamur Mikoriza Arbuskular di Tanah Salin. Universitas Sumatera Utara, Medan. 
- Arifiani, F.N., Kurniasih, B. dan Rogomulyo, R., 2018. Pengaruh Bahan Organik Terhadap Pertumbuhan dan Hasil Padi (Oryza sativa L.) Tercekam Salinitas. Vegetalika. 7(3): 30-40.

- Azarmi, R., R.D. Taleshmikail, A. Gikloo. 2010. Effects of salinity on morphological and physiological changes and yield of tomato in hydroponic system. J. Food. Agric. Environ. 8: 573-576.

- Drevan., 2011. Vitamin C Asam Askorbat. Jurnal Stigma, 8 (7) : 43-76.

-El-Ramady, H., lshaal, T., Elhawat, N., Ghazi, A., Elsakhawy, T., Omara, A.E., ElNahrawy, S., Elmahrouk, M., Abdalla, N., Domokos-Szabolcsy, E. and Schnug, E., 2018. Plant Nutrients and Their Roles Under Saline Soil Conditions. Springer Nature Singapore Pte Ltd. 297-324. https://doi.org/10.1007/978-981-10-90448_13.

- Farouk, S., 2011. Asam askorbat dan $\alpha$-tokoferol meminimalkan penuaan daun gandum akibat garam. Jurnal Fisiologi Stres \& Biokimia. Vol.7 No.3.

- Hasan, A.A., 2017. Pengaruh Asam Askorbat Dan Sodium Acid Pyrophosphate (Sapp) Dalam Mencegah Kerusakan Antioksidan Ubijalar Ungu Varietas Antin 3. Journal of Agritech Science, Vol 1 No 2.

- Koyro, H.W., 2006. Effect of salinity on growth, photosynthesis, water relations and solute composition of the potential cash crop halophyte Plantago coronopus L. Environmental and Experimental Botany. 56: 136-146.

- Krismiratsih, F., Winarso, S.dan Slamerto., 2020. Cekaman Garam NaCl danTeknik

- Aplikasi Azolla pada Tanaman Padi. Jurnal Ilmu Pertanian Indonesia (JIPI). Vol. 25 (3): 349 - 355. DOI: 10.18343/jipi.25.3.349

- Kurniawati, S., 2014. Pola Akumulasi Prolin dan Poliamin Beberapa Aksesi Tanaman Terung pada Cekaman Kekeringan. J. Agron. Indonesia, 42(2): 136-141.

- Mazher, A.A., E.F. El-Quesni, M.M. Farahat. 2007. Responses of ornamental and woody trees to salinity. World J. Agric. Sci. 3: 386-395.

- Nemati, I., F. Moradi, S. Gholizadeh, M.A. Esmaeili. and Bihamta, M.A., 2011., The effect of salinity stress on ions and soluble sugars distribution in leaves, leaf sheaths and roots of rice (Oryza sativa L.) seedlings. Plant Soil Environ. 57: 2633.

- Novenda, I.L. dan Nugroho, S.A., 2016. Analisis Kandungan Prolin Tanaman Kangkung (Ipomoea reptana Poir), Bayam (Amaranthus spinosus), dan Ketimun (Cucumis sativus). Pancaran, 5(4): 223-234.

- Novi, R.M.S., Joko. dan Ishak, J., 2016. Identifikasi Nilai Salinitas Pada Lahan Pertanian di Daerah Jungkat Berdasarkan Metode Daya Hantar Listrik (DHL). PRISMA FISIKA, Vol. IV, No. 02 (2016), Hal. 69-72. ISSN : 2337-8204.

- Novita, A., Luthfi, A. M. Siregar. dan Rosmayati., 2015. Respon Pertumbuhan dan Produksi Rosella (Hibiscus Sabdariffa L.) Pada Tanah Salin Dengan Pemberian Asam

\author{
Jurnal Serambi Ilmu \\ Journal of Scientific Information and Educational Creativity
}


Salisilat dan Giberelin $\left(\mathrm{GA}_{3}\right)$. Jurnal Pertanian Tropik. Vol. 2, No. 3, Hal. 258-263. ISSN Online No : 2356-4725.

- Novita, A., 2020. Respons of Early Growth Vetiver (Vetiveria Zizanioides L.) Seedling on Salt Stress Condition. Jurnal Pertanian Tropik. Vol.7.No.3. 2020 (37) 272- 276.

- Nurbaiti., 2019. Strategi Peningkatan Prestasi Belajar Siswa Melalui Pedekatan Model Problem Based Learning Berbantuan Matlab. Jurnal Serambi Ilmu, Vol. 20, No.2: 330-347.

- Oktaviani, C., Nurmaliah, C. dan Mahidin., 2019. Upaya Pengembangan Psikomotorik Peserta Didik Melalui Implementasi Problem Based Learning. Jurnal Serambi Ilmu, Vol. 20, No. 2.

- Pipit, D., Agustiansyah. dan Yayuk, N., 2014. Pengaruh Giberrelin (GA3 )Terhadap Pertumbuhan Dan Produksi Tanaman Kedelai (Glycine max (L.) Merrill). 276 Jurnal Agrotek Tropika 2(2):276-281 2014 J. Agrotek Tropika. ISSN 2337-4993. Vol. 2, No. 2: 276-281.

- Purwaningrahayu, R.D. dan Taufiq A. 2017. Respons morfologi empat genotip kedelai terhadap cekaman salinitas. Jurnal Biologi Indonesia. 13(2):175-188.

- Ruiz-Sánchez, M.C., R. Domingo, A. Torrecillas, A. Pérez-Pastor., 2000. Water stress preconditioning to improve drought resistance in young apricot plants. Plant Sci. 156: 245-251.

- Rachmawati, Rani, M.R., Defiani. dan Suriani, N.L,. 2009. Pengaruh Suhu dan Lama Penyimpanan terhadap Kandungan Vitamin C pada Cabai Rawit Putih (Capsicum frustescens). Jurnal Biologi XIII (2). Hal. $36-40$.

- Rahmawati, N., Ardiansyah, M. dan Mawarni. N., 2014. Respons Pertumbuhan Dan Produksi Kedelai Hasil Seleksi Terhadap Pemberian Asam Askorbat Dan Inokulasi Fungi Mikoriza Arbuskular Di Tanah Salin. J-Online Agroekoteknologi. ISSN No. 2337- 6597 Vol.2, No.3 : 948 - 954.

-Salama, Z.A., El-Nour, E.A.A.A., El Fouly, M.M. and Gaafar, A.A., 2014. Ascorbic foliar spray counteracting effect of salinity on growth, nutrients concentrations, photosynthesis, antioxidant activities and lipid peroxidation of Bean (Phaseulus vulgaris L.) cultivars . American Journal of Agricultural and Biological Sciences 9 (3) : 384 -3 93.

- Saragih, S., 2020. Tanggap Pertumbuhan Akar Wangi (Vetiveria zizanioides) Terhadap Pemberian Asam Askorbat Pada Kondisi Cekaman Salinitas. Repository UMSU. Medan.

- Sobir., Miftahudin. And Helmi, S., 2018. Respon Morfologi dan Fisiologi Genotipe Terung (Solanum melongena L.) terhadap Cekaman Salinitas. J. Hort. Indonesia, Agustus 2018, 9(2): 131-138.

- Sopandie, D. 2013. Fisiologi adaptasi tanaman Terhadap cekaman abiotik pada Agroekosistem Tropika. Bogor: IPB Press.

- Suárez-Hernández, A.M., Vázquez-Angulo, J.C., Grimaldo-Juárez, O., Ceceña-Durán, C., GonzálezMendoza, D., Bazante-González, I. and Mendoza-Gómez, A., 2019. 
Production and quality of grafted watermelon in saline soil. Horticultura Brasileira. 37(2): 215-219. https://doi.org/10.1590/s0102053620190213

- Sudjino, Triani, A. dan Hidayati. N., 2017. Pengaruh Salinitas Terhadap Pertumbuhan dan Perkembangan Tanaman Nyamplung (Callophylum Inophyllum L.) Dan Johar (Cassia Florida Vahl.) Dari Provenan Yang Berbeda. J Pemuliaan Tanaman Hutan Vol. 11 No. 2, Desember 2017, p. 99 - 111.

- Sulastri., 2016. Meningkatkan Prestasi Belajar Siswa Melalui Model Pembelajaran Interaktif Pada Pokok Bahasan Konduktor dan Isolator. Jurnal Serambi Ilmu, Vol. 22 No. 1, September 2015, p. 200-210.

- Temel, S., Keskin, B., Şimkek, U. and Yilmaza, I.H., 2016. The Effect of Saline and Non-Saline Soil Conditions on Yield and Nutritional Characteristics of Some Perennial Legumes Forages. Journal of Agricultural Sciences. 22: 528-538. https://doi.org/10.1501/ Tarimbil_0000001411

-Wijayanti, W., Taryono, Toekidjo. 2014. Keragaan 29 galur kacang tanah (Arachis hypogaea L.) pada kondisi salin. Vegetalika. 3: 40-51.

Wolucka, B. A., A. Goossens, and D. Inze. 2005. Methyl jasmonate stimulates the de novo biosynthesis of vitamin $\mathrm{C}$ in plant cell suspensions, J. Exp. Botany.56:25272538.

-Zhu, J.K., 2001. Plant Salt Tolerance. Trends Plant Science. 6(2): 66-71. https://doi.org/10.1016/ S1360-1385(00)01838-0

Copyright (C) 2021 Aisar Novita, Suwandi Saragih, Efrida Lubis, Abdul Rahman Cemda, Fitria, Rini Susanti, Silvia Nora, Arie Hapsani Hasan Basri, Merlyn Mariana' The manuscript open access article distributed under the Creative Commons Attribution License, which permits unrestricted use, distribution, and reproduction in any medium, provided the original work is properly cited.

Jurnal Serambi Ilmu

Journal of Scientific Information and Educational Creativity 